Nevada

Environmental

Restoration

Project

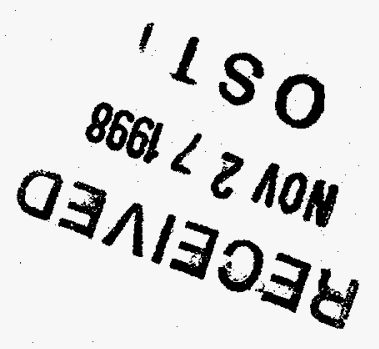

DOE/NV $/ 11718-215$

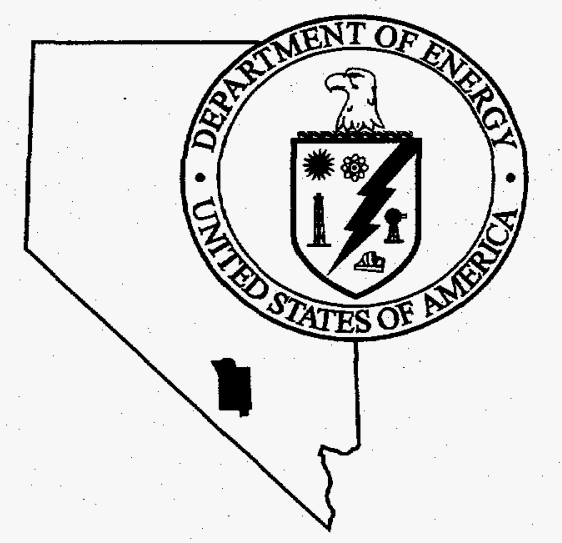

\title{
Closure Report for Corrective Action Unit 211 Area 15 EPA Farm Waste Sites Nevada Test Site, Nevada
}

Controlled Copy No.: OSTRROUTON OF THIS DOCUNENT IS UNLMHTED Ph

Revision: 0

April 1998 MASTER

Approved for public release; further distribution is authorized Environmental Restoration

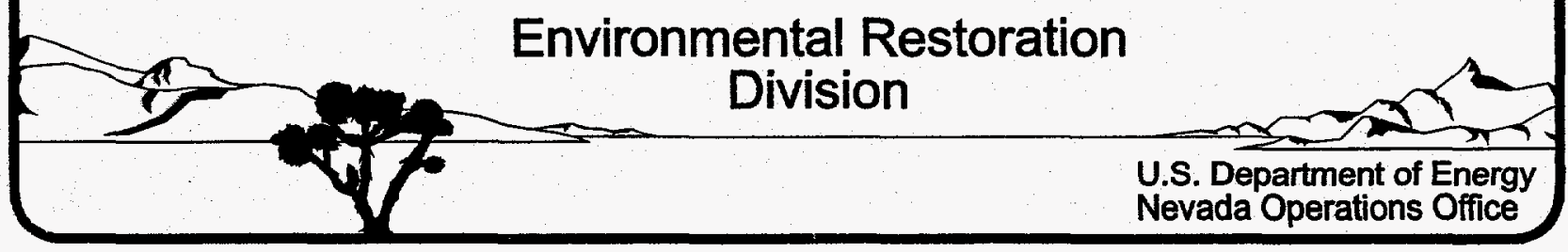




\section{DISCLAIMER}

This report was prepared as an account of work sponsored by an agency of the United States Government. Neither the United States Government nor any agency thereof, nor any of their empioyees, makes any warranty, express or implied, or assumes any legal liability or responsibility for the accuracy, completenesx, or usefulness of any information, apparatus, product, or process disclosed, or represents that its use would not infringe privately owned rights. Reference berein to any specific commercial product, process, or service by trade name, trademart, tranufacturer, or otherwise does not necessarily constinute or imply its endorsement, recom. mendation, or favoring by the United States Government or any ageacy thereof. The views and opinions of authors expressed herein do not oecessarily state or reflect those of the. United States Goverameat or any agency thereof. 


\section{DISCLAIMER}

Portions of this document may be illegible in electronic image products. Images are produced from the best available original document. 


\title{
CLOSURE REPORT FOR CORRECTIVE ACTION UNIT 211 AREA 15 EPA FARM WASTE SITES, NEVADA TEST SITE, NEVADA
}

\author{
Prepared for \\ U. S. Department of Energy \\ Nevada Operations Office \\ Under Contract No. DE-AC08-96NV11718
}

Controlled Copy No.:

Revision: 0

Prepared by

Bechtel Nevada

Environmental Restoration

April 1998 


\section{CLOSURE REPORT FOR CORRECTIVE ACTION UNIT 211 AREA 15 EPA FARM WASTE SITES \\ NEVADA TEST SITE, NEVADA}

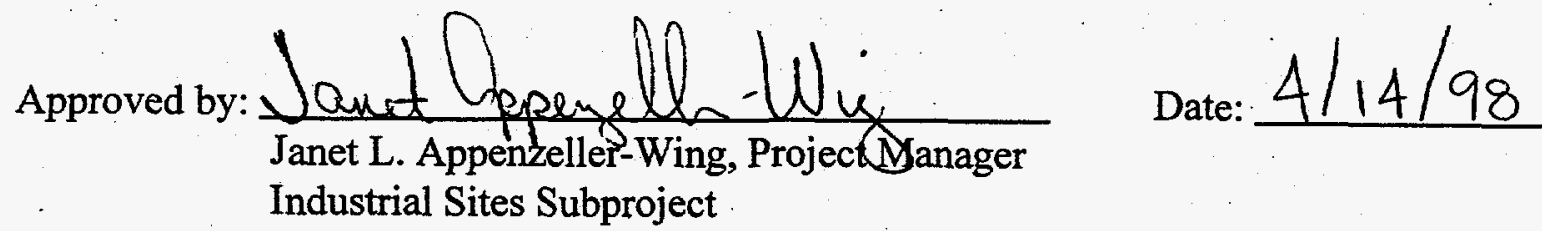

Approved by: $\frac{\text { Rolent Pn. Paryentes Qn. }}{\text { Runore C. Wycoff, Project Manager }}$
Nevada Environmental Restoration Project

Date: 4114198 


\section{SUMMARY OF CORRECTIVE ACTIONS FOR CAU 211}

\begin{tabular}{|c|c|c|}
\hline $\begin{array}{l}\text { Corrective Action } \\
\text { Site }\end{array}$ & Waste Description & Corrective Action \\
\hline $15-01-02$ & Scrap Metal & $\begin{array}{l}\text { Removed from site on October 1, } 1997 \\
\text { and transported to salvage. }\end{array}$ \\
\hline $15-01-06$ & Ordinary Debris & $\begin{array}{l}\text { Removed from site on September } 6 \text {, } \\
1997 \text { and transported to landfill. }\end{array}$ \\
\hline $15-19-01$ & Ordinary Debris & $\begin{array}{l}\text { Removed from site on September 25, } \\
1991 \text { for disposal. }\end{array}$ \\
\hline $15-22-31$ & Oil & $\begin{array}{l}\text { The material was determined to be a } \\
\text { non-hazardous petroleum hydrocarbon. } \\
\text { It was removed from site on September } \\
2,1997 \text {. Solidification and disposal was } \\
\text { completed on February } 11,1998 \text {. }\end{array}$ \\
\hline
\end{tabular}




\section{FFACO Corrective Action Site \\ Housekeeping Closure Verification Form \\ Closure Report for CAU 211: CAS 15-01-02}

Closure Verification Date: $24-$ OCT-97

CAS Number: 15-01-02

General Location: Area 15 EPA Farm

Latitude:

Longitude:
CAU Number: 211

Elevation: 4586 feet

Northing: 895,709

Easting: 682,084

Coordinate/Elevation data from Nevada Test Site Drilling \& Mining Summary, (prepared by Raytheon Services Nevada, 1991) based on water well UE15d located onsite.

Site Access Route: From Mercury take Mercury Highway north to Rainier Mesa Road, proceeding northwest, turn north onto 2-05 Road. Continue on 2-05 Road for 4.5 miles and go north at "y" onto Circle Road and continue for 5 miles. Turn north onto 10-02 Road and continue for 1.5 miles. Turn east and go to end of paved road. The EPA Farm complex is on the south.

\begin{tabular}{|l|l|}
\hline \multicolumn{1}{|c|}{ Waste Item(s) Originally at Site } & \multicolumn{1}{c|}{ Apparent Waste Type } \\
\hline Aboveground Storage Tanks & Scrap metal \\
\hline
\end{tabular}

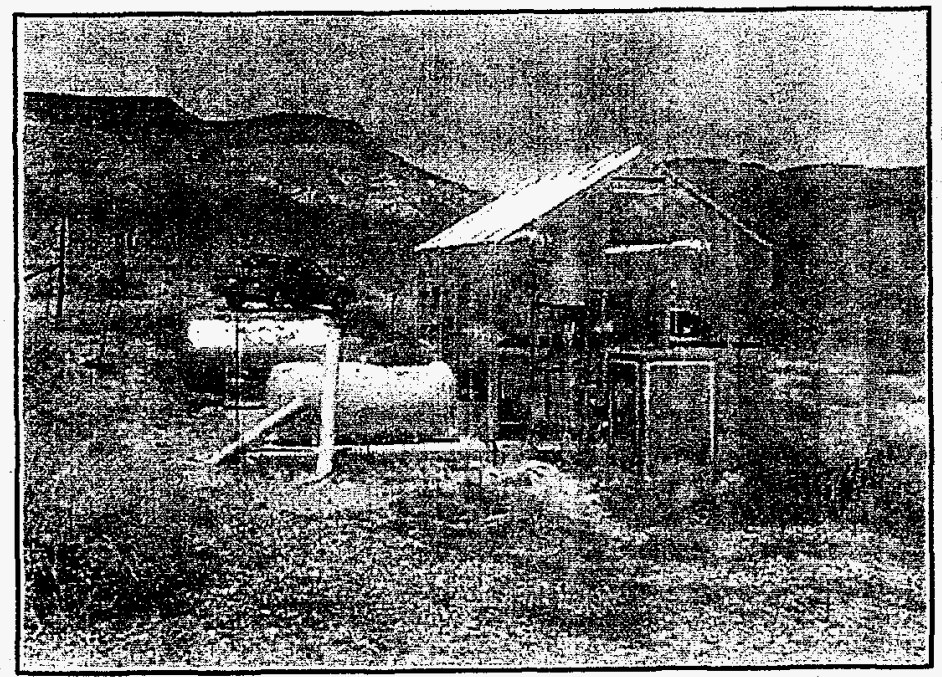

CAS Status Prior To Cleanup

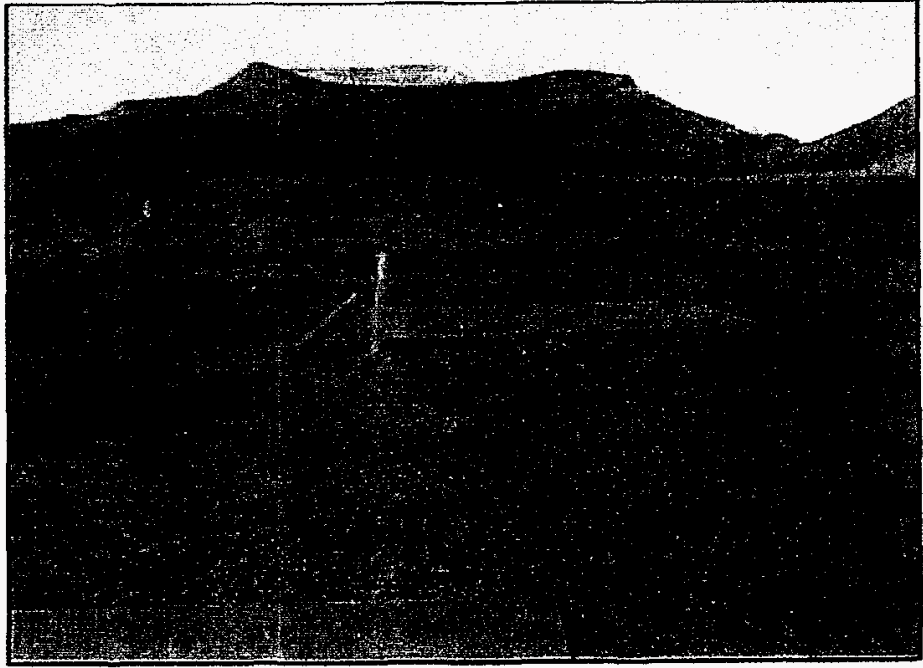

CAS Status After Cleanup

Current Site Description/Observations: Bechtel Nevada Environmental Restoration personnel determined through historical research, radiological survey, and visual inspection that the tanks were used for the storage of propane gas and water for use with the associated greenhouse. The tanks were removed from the site on October 1, 1997 and transported to the Area 23 Excess Yard to be salvaged as scrap metal.

No Further Action Required at Corrective Action Sige

Angela L. Olson

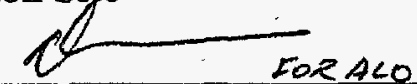

(Signature)

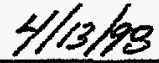

Date 


\section{FFACO Corrective Action Site \\ Housekeeping Closure Verification Form \\ Closure Report for CAU 211: CAS 15-01-06}

Closure Verification Date: $24-$ OCT-97

CAS Number: $15-01-06$

General Location: Area 15 EPA Farm

Latitude:

Longitude:

CAU Number: 211

Elevation: 4586 feet

Northing: 895,709

Easting: 682,084

Coordinate/Elevation data from Nevada Test Site Drilling \& Mining Summary, ( prepared by Raytheon Services Nevada, 1991) based on water well UE15d located onsite.

Site Access Route: From Mercury take Mercury Highway north to Rainier Mesa Road, proceeding northwest, turn north onto 2-05 Road. Continue on 2-05 Road for 4.5 miles and go north at " $y$ " onto Circle Road and continue for 5 miles. Turn north onto 10-02 Road and continue for 1.5 miles. Turn east and go to end of paved road. The EPA Farm complex is on the south.

\begin{tabular}{|l|l|}
\hline \multicolumn{1}{|c|}{ Waste Item(s) Originally at Site } & \multicolumn{1}{|c|}{ Apparent Waste Type } \\
\hline Aboveground Storage Tank & Ordinary Debris \\
\hline
\end{tabular}

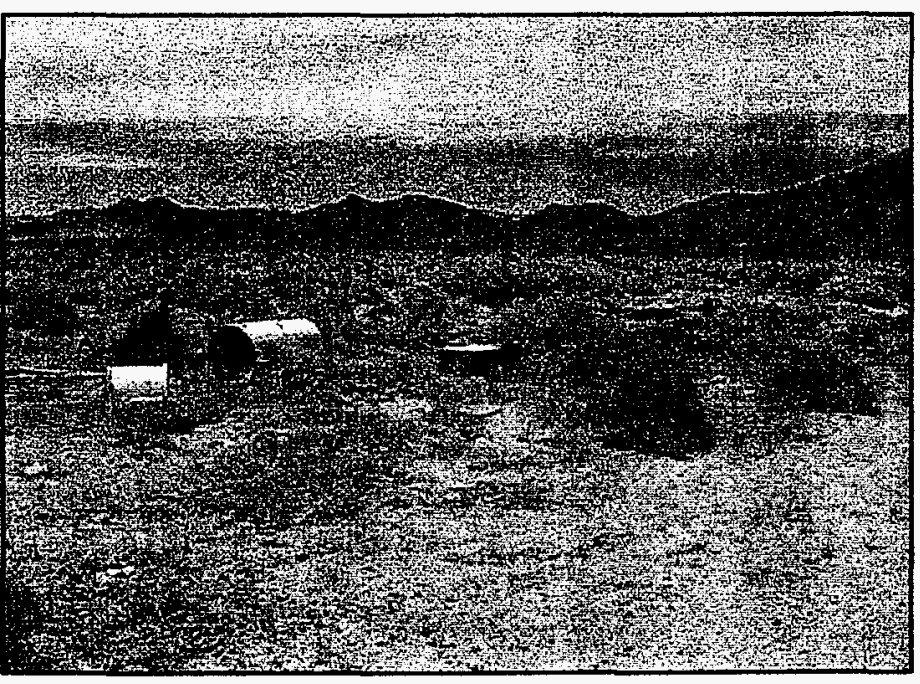

CAS Status Prior To Cleanup

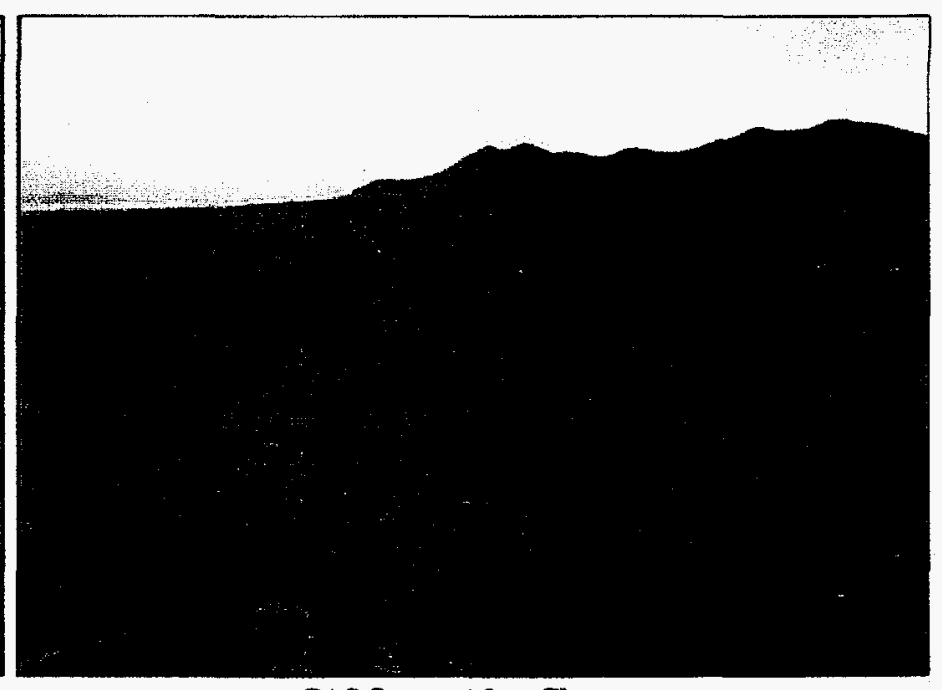

CAS Status After Cleanup

CURRENT Site Description/Observations: Bechtel Nevada Environmental Restoration personnel determined through historical research, radiological survey, and visual inspection that the tank was part of the original water chlorination system used at the farm and had not been used for the storage of hazardous substances. The tank was removed from the site on September 6,1997 and transported to the Area 9 10c Sanitary Landfill as ordinary debris.

$\checkmark$ No Further Action Required at Corrective Action Site

Angela L. Olson

Corrective Action Coordinator/Designee

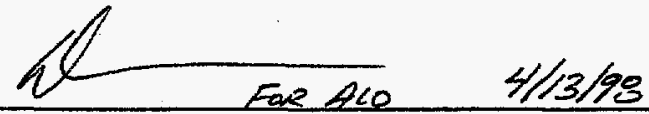

(Signature)
Date 


\section{FFACO Corrective Action Site Housekeeping Closure Verification Form Closure Report for CAU 211: CAS 15-19-01}

Closure Verification Date: 26-FEB-98

CAS Number: 15-19-01

General Location: EPA Farm/Climax Mine

Latitude: 37.231270

Longitude: -116.056026

\author{
CAU Number: 211 \\ Elevation: 5219 feet \\ Northing: \\ Easting:
}

Coordinate/Elevation Data Obtained from Garmen 40 Global Position System: Accuracy is within $300 \mathrm{ft}$ Horizontai - Vertical Varies with Locality

Site Access Route: North on "D" Road approximately 2 miles from the Area 15 former EPA Farm site, to old miner's shack. Go west approx. 0.2 miles to dump on right, turning right (north) toward drill pad and shaft. The CAS lies along the west side of the dirt road.

\begin{tabular}{|l|l|}
\hline \multicolumn{1}{|c|}{ Waste Item(s) Originally at Site } & Apparent Waste Type* \\
\hline Empty Chemical Containers, Trash & Ordinary \\
\hline
\end{tabular}

* Ordinary, Scrap Metal, Asbestos, PCB, Salvageable, Hazardous, Radioactive, Mixed, Uniknown, Other

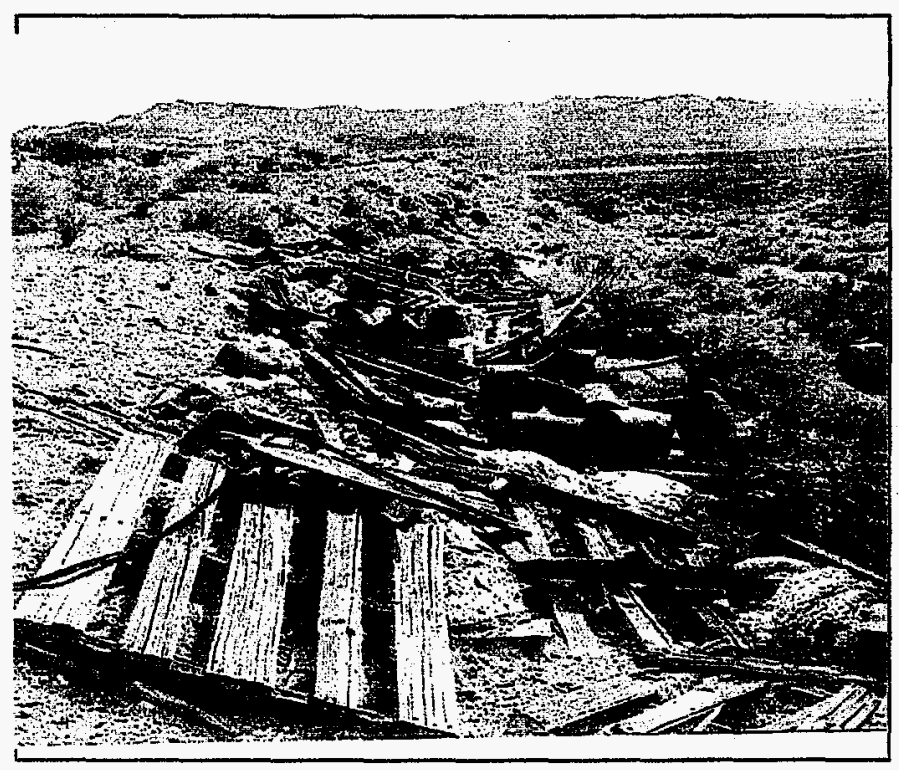

CAS Status Prior to Cleanup

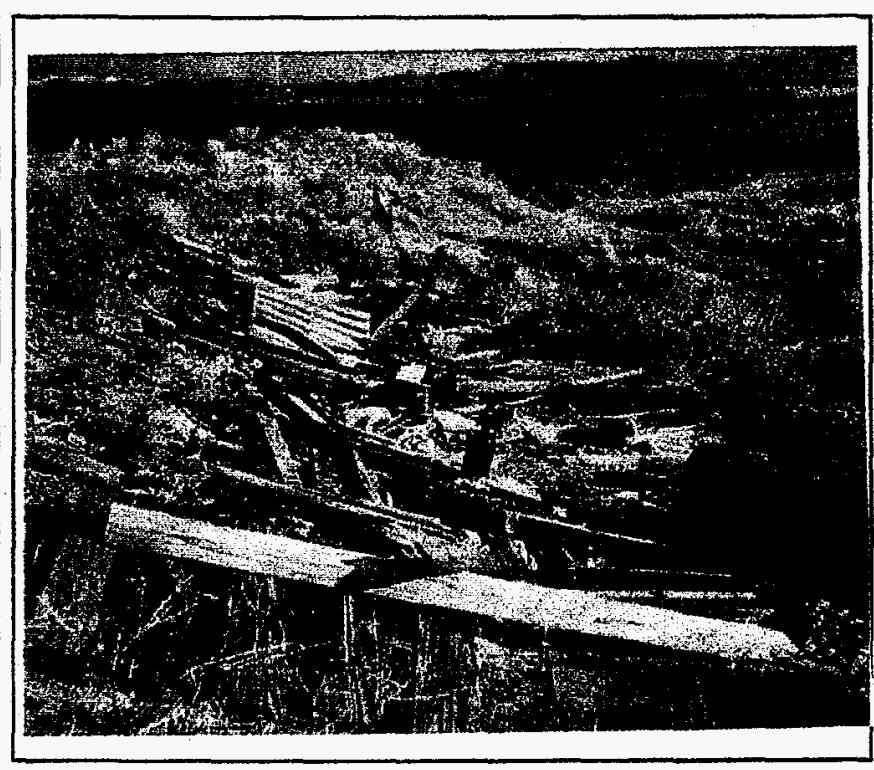

CAS Status After Cleanup

Current Site Description/Observations: The waste originally identified at this CAS was retrieved for disposal on 25-SEP-91. There is wood debris and ancillary waste remaining at this location which will be re-visited for retrieval under a separate program, outside of FFACO corrective actions. All metal containers retrieved from this site were empty and no soil staining was observed.

No Further Action Required at Corrective Action Site

C. Carios Gonzales

Corrective Action Coordinator/Designee

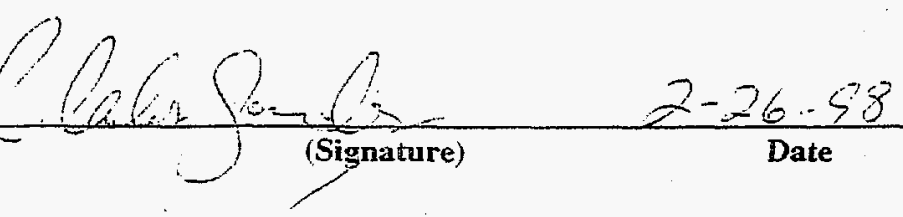




\section{FFACO Corrective Action Site Housekeeping Closure Verification Form Closure Report for CAU 211: CAS 15-22-31}

Closure Verification Date: $24-$ OCT-97

CAS Number: 15-22-31

General Location: Area 15 EPA Farm

Latitude:

Longitude:
CAU Number: 211

Elevation: 4586 feet

Northing: 895,709

Easting: 682,084

Coordinate/Elevation data from Nevada Test Site Drilling \& Mining Summary, (prepared by Raytheon Services Nevada, 1991) based on water well UE1 Sd located onsite.

Site Access Route: From Mercury take Mercury Highway north to Rainier Mesa Road, proceeding northwest, turn north onto 2-05 Road. Continue on 2-05 Road for 4.5 miles and go north at " $y$ " onto Circle Road and continue for 5 miles. Turn north onto 10-02 Road and continue for 1.5 miles. Turn east and go to end of paved road. The EPA Farm complex is on the south.

\begin{tabular}{|l|l|}
\hline \multicolumn{1}{|c|}{ Waste Item(s) Originally at Site } & \multicolumn{1}{c|}{ Apparent Waste Type } \\
\hline Fuel oil can & Oil \\
\hline
\end{tabular}

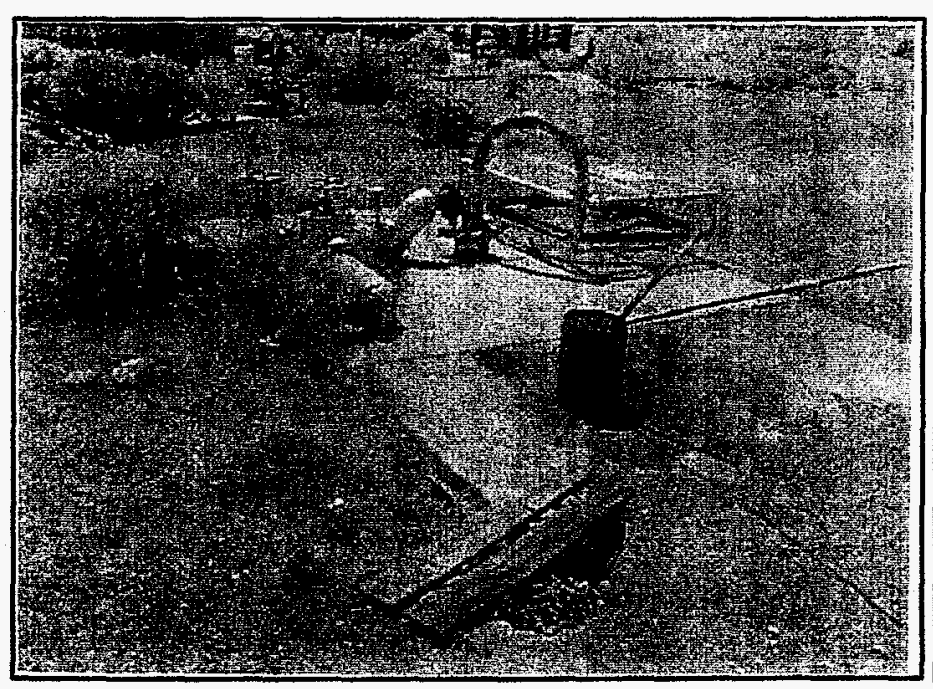

CAS Status Prior To Cleanup

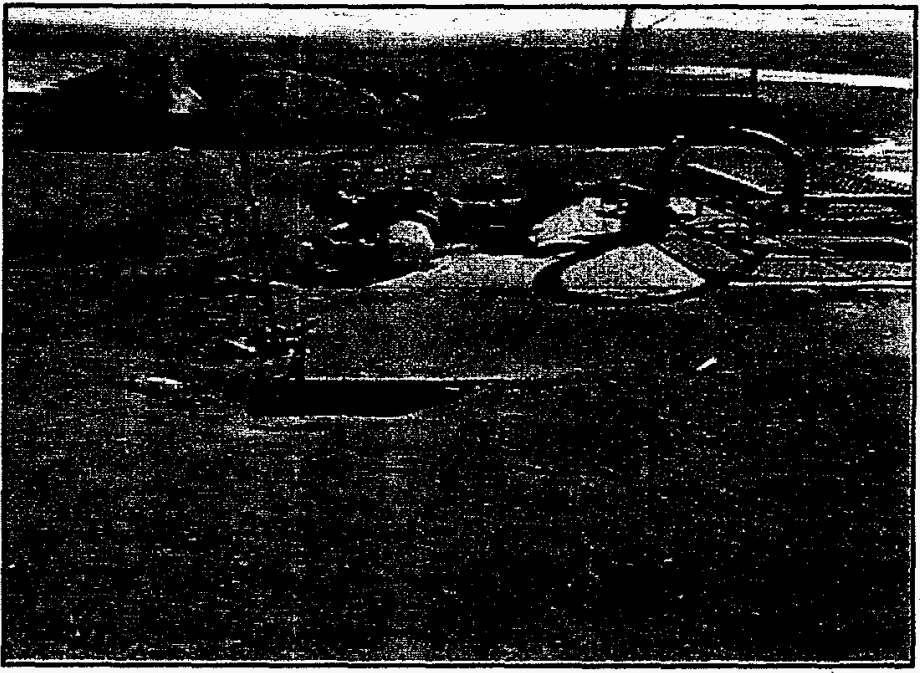

CAS Status After Cleanup

Current Site Description/Observations: Bechtel Nevada Nonradioactive Waste Management Project personnel sampled the contents of the can on September 2, 1997. Analytical results indicated that the contents were nonhazardous petroleum hydrocarbons. The contents were solidified with clean soil and disposed of in the Area 9 10c Sanitary Landfill on February 11, 1998.

No. Further Action Required at Corrective Action Site

Angela L. Olson

Corrective Action Coordinator/Designee

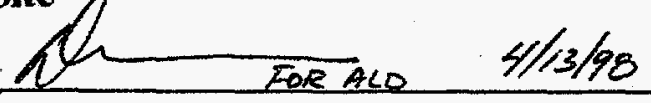

(Signature) $\vdots$ Date 


\section{DISTRIBUTION LIST}

\section{Copies}

Controlled

\section{Bureau of Federal Facilities}

Division of Environmental Protection

333 W. Nye Lane, Room 13B

Carson City, NV 89706-0866

P. J. Liebendorfer

D. A. Garrepy

U.S. Department of Energy, Nevada Operations Office

P. O. Box 98518,505

Las Vegas, NV 89193-8518

S. D. Bonnell

U.S. Department of Energy, Nevada Operations Office

P. O. Box 98518, 505

Las Vegas, NV 891.93-8518

Janet L. Appenzeller-Wing

C. W. Barrow

Public Reading Room

Technical Information Resource Center

U. S. Department of Energy,

Office of Scientific and Technical Information

P. O. Box 62

Oak Ridge, TN 37831 


\section{DISTRIBUTION LIST (continued)}

\section{Uncontrolled Copies}

\section{Bechtel Nevada}

P. O. Box 98521, M/S NLV008

Las Vegas, NV 89193-8521

Correspondence Control

D. K. Cowser

D. D. Madsen

S. J. Nacht

A. L. Olson

K. A. Quintana 